\title{
ONE MORE TURÁN NUMBER AND RAMSEY NUMBER FOR THE LOOSE 3-UNIFORM PATH OF LENGTH THREE
}

\author{
JOANNA POLCYN \\ Adam Mickiewicz University \\ Poznań, Poland \\ e-mail: joaska@amu.edu.pl
}

\begin{abstract}
Let $P$ denote a 3-uniform hypergraph consisting of 7 vertices $a, b, c, d$, $e, f, g$ and 3 edges $\{a, b, c\},\{c, d, e\}$, and $\{e, f, g\}$. It is known that the $r$ color Ramsey number for $P$ is $R(P ; r)=r+6$ for $r \leqslant 9$. The proof of this result relies on a careful analysis of the Turán numbers for $P$. In this paper, we refine this analysis further and compute the fifth order Turán number for $P$, for all $n$. Using this number for $n=16$, we confirm the formula $R(P ; 10)=16$.
\end{abstract}

Keywords: Ramsey numbers, Turán numbers.

2010 Mathematics Subject Classification: 05D10.

\section{REFERENCES}

[1] R. Csákány and J. Kahn, A homological approach to two problems on finite sets, J. Algebraic Combin. 9 (1999) 141-149.

doi:10.1023/A:1018630111976

[2] P. Erdös, C. Ko and R. Rado, Intersection theorems for systems of finite sets, Q. J. Math. 12 (1961) 313-320.

doi:10.1093/qmath/12.1.313

[3] P. Frankl and Z. Füredi, Exact solution of some Turán-type problems, J. Combin. Theory Ser. A 45 (1987) 226-262.

doi:10.1016/0097-3165(87)90016-1

[4] P. Frankl and Z. Füredi, Non-trivial intersecting families, J. Combin. Theory Ser. A 41 (1986) 150-153. doi:10.1016/0097-3165(86)90121-4

[5] Z. Füredi, T. Jiang and R. Seiver, Exact solution of the hypergraph Turán problem for k-uniform linear paths, Combinatorica 34 (2014) 299-322. doi:10.1007/s00493-014-2838-4 
[6] A. Gyárfás and G. Raeisi, The Ramsey number of loose triangles and quadrangles in hypergraphs, Electron. J. Combin. 19 (2012) \# R30.

[7] J. Han and Y. Kohayakawa, The maximum size of a non-trivial intersecting uniform family that is not a subfamily of the Hilton-Milner family, Proc. Amer. Math. Soc. 145 (2017) 73-87.

doi: $101090 / \mathrm{proc} / 13221$

[8] A.J.W. Hilton, and E.C. Milner, Some intersection theorems for systems of finite sets, Q. J. Math. 18 (1967) 369-384.

doi:10.1093/qmath/18.1.369

[9] E. Jackowska, The 3-color Ramsey number for a 3-uniform loose path of length 3, Australas. J. Combin. 63 (2015) 314-320.

[10] E. Jackowska, J. Polcyn and A. Ruciński, Turán numbers for linear 3-uniform paths of length 3, Electron. J. Combin. 23(2) (2016) \#P2.30.

[11] E. Jackowska, J. Polcyn and A. Ruciński, Multicolor Ramsey numbers and restricted Turán numbers for the loose 3-uniform path of length three, submitted.

[12] A. Kostochka, D. Mubayi and J. Verstraëte, Turán problems and shadows I: paths and cycles, J. Combin. Theory Ser. A 129 (2015) 57-79 doi:10.1016/j.jcta.2014.09.005

[13] G.R. Omidi and M. Shahsiah, Ramsey numbers of 3-uniform loose paths and loose cycles, J. Combin. Theory Ser. A 121 (2014) 64-73. doi:10.1016/j.jcta.2013.09.003

[14] J. Polcyn and A. Ruciński, A hierarchy of maximal intersecting triple systems, Opuscula Math. 37(4) (2017), to appear.

arXiv:1608.06114

[15] J. Polcyn and A. Ruciński, Refined Turán and Ramsey numbers for the loose 3uniform path of length three, Discrete Math. 340 (2017) 107-118. doi:10.1016/j.disc.2016.08.006

Received 28-12-2015

Revised 9-05-2016

Accepted 9-05-2016 